\title{
Pengaruh Insentif Terhadap Prestasi Kerja Karyawan Housekeeping Pada Hotel Furaya Pekanbaru
}

\author{
Maryantina \\ Sekolah Tinggi Pariwisata Riau \\ Jl. Pattimura No.54 Gobah Pekanbaru, email.maryant@gmail.com \\ HP.085271597810
}

\begin{abstract}
Hotel Furaya need to improve the quality of human resources in providing services to consumers. Seeing the importance of the position of human resources at the Hotel Furaya, it may be reasonable for management to give more attention through the wisdom of wisdom taken. Through research by using descriptive statistics and distributing questionnaires to 218 employees are aware that there is a significant relationship between the incentive and employee performance Housekeeping at Hotel Furaya Pekanbaru, then H0 is rejected Ha accepted Under the policy further motivate employees to work better for career advancement in the future.
\end{abstract}

Keywords: employee job performance and Incentives

Pada era globalisasi, dunia usaha telah berkembang dengan pesat yang ditandai dengan munculnya perusahaan perusahaan baru sehingga mengakibatkan atmosfir persaingan antara perusahaan akan menjadi semakin ketat. Salah satu syarat suatu perusahaan dapat bertahan dan memenangkan persaingan adalah dengan melaksanakan proses produksi secara lebih efektif dan efisien dibandingkan dengan pesaingnya. Sumber Daya Manusia (SDM) merupakan salah satu faktor produksi dalam menentukan keberhasilan perusahaan. Karyawan adalah asset utama perusahaan yang menjadi perencana dan pelaku aktif dari setiap aktivitas perusahaan. Dalam hal ini diperlukan pengetahuan tentang bagaimana mengarahkan para karyawan dengan baik agar mau bekerja dengan semaksimal mungkin. Untuk mewujudkan tujuan ini, maka diperlukan karryawan yang terampil, berprestasi dan profosional sehingga karyawan akan selalu tanggap dengan kebutuhan perusahaan.

Hotel Furaya merupakan salah satu hotel berbintang tiga yang beroperasi di kota pekanbaru, mengingat ketatnya persaingan dalam usaha jasa akomodasi, Hotel Furaya perlu meningkatkan kualitas sumber daya manusia dalam memberikan pelayanan kepada konsumen. Melihat pentingnya kedudukan sumber daya manusia di Hotel Furaya, maka layak bagi manajemen untuk memberi perhatian yang lebih melalui kebijaksanaan kebijaksanaan yang diambil. Hal ini bertujuan agar karyawan dapat memberikan kontribusi kepada kepada perusahaan dengan memanfaatkan pengetahuan dan keterampilan yang mereka miliki kepada perusahaan demi kelancaran proses produksi dan jalannya perusahaan. Keberhasilan suatu perusahaan dalam mencapai tujuan, sasaran serta kemampuannya menghadapi berbagai tantangan, baik yang bersifat eksternal maupun internal sangat ditentukan oleh kemampuan menggelola sember daya manusia secara tepat.

Berikut Rekapitulasi Penjualan Kamar Hotel Furaya dari Tahun 2012, 2013, 2014 : penjualan kamar Hotel Furaya dari tahun 2012, 2013, 2014 mengalami penurunan, tetapi di tahun 2012 dan 2013 hasil penjualan mencapai target sedangkan 2013 target tidak tercapai. Kompensasi menurut Hariandja (2005:244), merupakan keseluruhan balas jasa yang diterima oleh pegawai sebagai akibat dari pelaksanaan pekerjaan dari perusahaan dalam bentuk uang atau lainnya, yang dapat berupa gaji, 
upah, insentif dan tunjangan lain seperti tunjangan kesehatan, tunjangan hari raya, uang makan, uang cuti dan sebagainya. Kompensasi dalam suatu perusahaan merupakan masalah yang sangat komplek dan penting bagi karyawan maupun perusahaan itu sendiri. Pembberian kompensasi kepada karyawan harus mempunyai dasar yang rasional namun demikian factor emosional dan prikemanusiaan tidak boleh diabaikan.

Bagi karyawan, kompensasi menjadi suatu ukuran nilai karya mereka baik di antara para karyawan itu sendiri, keluarga maupun masyarakat. Pendapatan yang diperoleh karyawan menunjukkan status, martabat dan harga diri karyawan tersebut. Bagi perusahaan, kompensasi merupakan pencerminan upaya perusahaan untuk mempertahankan sumber daya manusia yang ada. Perusahaan yang tidak mampu memberikan kompensasi secara tepat pada karyawannya, kemungkinan perusahaan tersebut lambat laun akan kehilangan sumber daya manusia manusia berkompetensi tinggi yang telah dimilikinya.

Tujuan insentif dimaksud sebagai pemberian salah satu bentuk penghargaan kepada karyawan atas sumbangannya kepada organisasi yang tercermin dari prestasi kerjanya ( Siagian, 2003 : 258 ). Insentif yang diberikan dapat berupa insentif financial dan insentif non financial. Karyawan akan mempunyai prestasi kerja yang tinggi jika pemberian insentif dilakukan secara adil, layak dan memadai. Hotel Furaya Pekanbaru menerapkan insentif sebagai salah satu cara untuk meningkatkan prestasi kerja karyawan, baik insentif financial ataupun non financial. Tetapi insentif yang diterima karyawan lebih kecil dari gaji pokok, sehinga sebagian karyawan ada yang membandingkan dengan hotel lain kenapa hotel lain insentifnya besar dari gaji pokok, ada juga karyawan lain dengan insentif yang mereka terima mereka bekerja dengan sesuai yang mereka dapat, dan ada juga karyawan mengatakan tidak adil karena disaat pendapatan hotel meningkat insentifnya tetap seperti itu juga dan ada juga sebagian karyawan yang bekerja dengan semangat karena mereka berpikir itu sudah peraturan hotel tersebut.

Prestasi kerja adalah hasil pelaksanaan suatu pekerjaan, baik bersifat fisik/material maupun non fisik/non material yang dalam melaksanakan tugasnya berdasarkan deskripsi pekerjaan perlu dinilai hasilnya setelah tenggang waktu tertentu ( Nawawi 2005). Menurut Hasibuan (2001) prestasi kerja adalah suatu hasil kerja yang dicapai seseorang dalam melaksanakan tugas tugas yang diberikan kepadanya yang didasarkan atas kecakapan, pengalaman dan kesungguhan serta waktu.

Kompensasi tidak langsung merupakan kompensasi tambahan yang diberikan berdasarkan kebijakan perusahaan terhadap semua karyawan sebagai upaya maningkatkan kesejahteraan para karyawan . Contohnya berupa fasilitas fasilitas seperti asuransi asuransi, tunjangan tunjangan dan uang pension. Menurut Rivai (2004:359) perusahaan memberikan kompensasi terhadap karyawan bertujuan: Memperoleh Sumberdaya manusia yang berkualitas.

Kompensasi yang cukup tinggi sangat dibutuhkan untuk member daya tarik kepada pelamar. Tingkat pembayaran harus responsive terhadap penawaran dan permintaan pasar kerja karena para pengusaha berkompetisi untuk mendapatkan karyawan yang diharapkan. Mempertahankan Karyawan yang ada. Para karyawan dapat keluar jika besaran kompensasi tidak kompetif dan akibat akan menimbulkan perputaran karyawan yang semakin tinggi. Menjamin keadilan. Manajemen kompensasi selalu berupaya agar keadilan internal dan eksternal dapat terwujud. Keadilan internal mensyaratkan bahwa pembayaran dikaitkan dengan nilai relative sebuah pekerjaan sehingga pekerjaan yang sama dibayar dengan bayaran yang sama.

Tujuan kompensasi menurut Hasibuan (2000:121) adalah sebagai berikut: Menarik pelamar yang potensial. Dalam hubungannya dengan upaya p.ISSN: $2407-800 X \quad$ e.ISSN: 2541-4356 
recruitment dan seleksi perusahaan, program kompensasi total dapat membantu memastikan bahwa pembayaran cukup untuk menarik orang yang tepat, pada waktunya yang tepat dan pekerjaan yang cepat. Mempertahankan karyawan yang baik. Jika program kompensasi total dirasakan tidak adil secara internal maka karyawan yang baik (karyawan yang ingin dipertahankan perusahaan ) mungkin akan keluar. Melakukan pembayaran sesuai aturan hukum. Beberapa aturan hokum yang relavan dengan kompensasi total. Perusahaan harus sadar akan hal ini dan menghindari penyimpangan terhadap peraturan peraturan ini dalam program pembayarannya.

Insentif adalah bentuk pembayaran langsung yang didasarkan atau dikaitkan langsungdengan kinerja dan pembagian keuntungan bagi pegawai akibat peningkatan produktivitas atau penghematan biaya. Insentif umumnya dilakukan sebagai strategi untuk meningkatkan produktivitas dan evisiensi perusahaan dengan memanfaatkan perilaku pegawai yang mempunyai kecenderungan kemungkinan bekerja seadanya atau tidak optimal , Hariandja (2002:265). Berdasarkan uraian diatas maka dapat disimpulkan bahwa insentif merupakan salah satu bentuk rangsangan atau motivasi yang sengaja diberikan kepada karyawan untuk mendorong semangat kerja karyawan agar mereka bekerja lebih produktif lagi, meningkatkan prestasinya dalam mencapai tujuan perusahaan.

Menurut ahli manajemen sumber daya manusia Sondang P. Siagian (2002: 268), jenis jenis insentif tersebut adalah: Piece work ( upah per output ). Piece work adalah teknik yang digunakan untuk mendorong kinerja pegawai berdasarkan hasil pekerjaan pegawai yang dinyatakan dalam jumlah unit produksi; Bonus. Bonus adalah insentif yang diberikan kepada pegawai yang mampu bekerja sedemikian rupa sehingga tingkat produksi yang baku telampaui; Komisi. Komisi adalah bonus yang diterima karena berhasil melaksanakan tugas dan sering diterapkan oleh tenagatenaga penjual; Kurva " kematangan".
Adalah diberikan kepada tenaga kerja yang karena masa kerja dan golongan pangkat serta gaji tidak bias mencapai pangkat dan penghasilan yang lebih tinggi lagi, misalnya dalam bentuh penelitian ilmiah atau dalam bentuk beban mengajar yang lebih besar dan sebagainya; Rencana insentif kelompok. Rencana insentif kelompok adalah kenyataan bahwa dalam banyak organisasi, kinerja bukan karena keberhasilan individual melainkan karena keberhasilan kelompok kerja yang mampu bekerja sebagai suatu tim.

Ada beberapa jenis insentif menurut Sarwoto ( 2000:144) secara garis besar jenis insentif dapat digolongkan menjadi dua yaitu sebagai berikut: Insentif Material. Uang dan barang insentif ini dapat diberikan dalam berbagai macam, antara lain. Bonus, terbagi atas : (1) Uang yang dibayarkan sebagai balas jasa atas hasil pekerjaan yang telah dilaksanakan (2) Dalam perusahaan yang menggunakan system insentif lazimnya beberapa persen dari laba yang melebihi jumlah tertentu dimasukkan ke dalam sebuah dana dan kemudian jumlah tersebut dibagi-bagi antara pihak yang akan diberikan bonus. Komisi, Merupakan sejenis komisi yang dibayarkan kepada pihak bagian bagian pennjualan yang menghasilkan penjualan yang baik. Jaminan Sosial, Insentif yang diberikan dalam bentuk jaminan sosial lazimnya diberikan secara kolektif, tidak ada unsur kompetitif dan setiap pegawai dapat memperolehnya secara rata-rata dan otomatis. Bentuk jaminan sosial berupa: (a) Pemberian rumah dinas. (b) Pengobatan secara Cuma Cuma. (c) Kemungkinan untuk pembayaran secara angsuran oleh pekerja atas barang-barang yang dibelinya dari koperasi organisasi. (d) Cuti sakit. (e). Biaya pindah; Insentif Non Material. Insentif non material dapat diberikan dalam berbagai bentuk: Pemberian gelar secara resmi, Pemberian tanda jasa, Pemberian piagam penghargaan, Pemberian kenaikan pangkat.

Tujuan Pemberian Insentif. Fungsi
utama dari insentif adalah untuk

p.ISSN: $2407-800 X \quad$ e.ISSN: 2541-4356 
memberikan tanggung jawab dan dorongan kepada karyawan. Insentif menjamin bahwa karywan akan mengarahkan usahanya untuk mencapai tujuan organisasi. Sedangkan tujuan utama pemberian insentif adalah untuk meningkatkan produktifitas kerja individu maupun kelompok ( Pangabean, 2002:93).

Secara lebih spesifik tujuan pemberian insentif dapat dibedakan dua golongan yaitu: Bagi Perusahaan. Tujuan dari pelaksanaan insentif dalam perusahaan khususnya dalam kegiatan produksi adalah untuk meningkatkan produktivitas kerja karyawan jengan jalan mendorong/merangsang agar karyawan: Bekerja lebih bersemangat dan cepat. Bekerja lebih disiplin. Bekerja lebih kreatif. Bagi Karyawan.

Dengan adanya pemberian insentif karyawan akan mendapatkan keuntungan: Standar prestasi dapat diukur secara kuantitatif; Standar prestasi diatas dapat digunakan sebagai dasar pemberian balas jasa yang diukur dalam bentuk uang; Karyawan harus lebih giat agar dapat menerima uang lebih besar. Hariandja (2002:246) menerangkan bahwa : "Insentif merupakan salah satu factor yang penting dalam meningkatkan prestasi kerja, motivasi pegawai, merangsang pegawai baru yang berkualitas untuk memasuki organisasi , mempertahankan pegawai yang ada dan meningkatkan produktivitas organisasi”.

\section{METODE}

Populasi dalam penelitian ini seluruh karyawan hotel furaya pekanbaru yang berjumlah 218 orang. Teknik sampling yang digunakan untuk menentukan banyaknya sampel adalah Sampel Random Sampling, yaitu suatu teknik pemilihan sampel yang dilakukan secara random (acak) sehingga setiap populasi memiliki kesempatan yang sama untuk menjadi sampel. Pengumpulan data menggunakan kueioner dan data yang diperoleh dari observasi, study pustaka dan wawancara serta angket yang dipilih pilih dan klasifikasi menurut jenisnya dan kemudian dinanlisis serta diolah dengan menggunakan metode deskriftif analitik.

\section{HASIL}

Untuk menjadi bagian dalam pembangunan kota Pekanbaru, maka didirikanlah Hotel Furaya yang terletak di Jalan Jend. Sudirman No. 72-74 Pekanbaru. Disekitar hotel terdapat pertokoan, swalayan, bank, Telkom, restoran, kantor pos dan giro. Karena letaknya yang strategis dan berada di tengah-tengah kota, tentu saja akan sangat menguntungkan bagi tamu yang menginab di hotel tersebut.

Koefisien determinasi digunakan untuk mengetahui persentase pengaruh variabel independen (predictor/X) terhadap perubahan variabel dependen $($ kriterium $/ \mathrm{Y})$. Untuk mengetahui besarnya sumbangan (kontribusi) variabel independen terhadap variabel dependen dilihat dengan mencari nilai koefisien determinasi atau penentu.

\begin{tabular}{|l|l|l|l|l|}
\hline Model & $\mathrm{R}$ & $\begin{array}{l}\mathrm{R} \\
\text { Square }\end{array}$ & $\begin{array}{l}\text { Adjusted } \\
\mathrm{R} \text { Square }\end{array}$ & $\begin{array}{l}\text { Std. Error of } \\
\text { the Estimate }\end{array}$ \\
\hline 1 & $.372^{\mathrm{a}}$ & .238 & .212 & 1.05650 \\
\hline
\end{tabular}

a. Predictors: (Constant), Insentif

b. Dependent Variable: Prestasi Kerja

Berdasarkan hasil perhitungan diperoleh nilai koefisien determinasi sebesar 0,238. Artinya variabel insentif yang terdiri dari insentif finansial dan nonfinansial memberikan kontribusi terhadap variabel prestasi kerja sebesar $23.8 \%$ dan sisanya $76.2 \%$ ditentukan oleh faktor-faktor lain yang tidak diteliti antara lain: bonus, komisi, jaminan sosial ( pemberian rumah dinas, pengobatan secara Cuma cuma), pemberian gelar secara resmi, pemberian tanda jasa, pemberian piagam penghargaan dan pemberian kenaikan pangkat.

Uji-t digunakan untuk mengetahui pengaruh masing-masing variabel bebas terhadap variabel terikat secara individual (parsial) dan untuk mengetahui variabel bebas yang mempunyai pengaruh yang dominan terhadap variabel terikat dengan mengukur hubungan antara variabel bebas dengan variabel terikat dengan asumsi variabel bebas lainnya bersifat tetap atau konstan. 


\begin{tabular}{|l|l|l|l|l|l|}
\hline \multirow{2}{*}{ odel } & \multicolumn{2}{|l|}{$\begin{array}{l}\text { Unstandardized } \\
\text { Coefficients }\end{array}$} & $\begin{array}{l}\text { Standardized } \\
\text { Coefficients }\end{array}$ & Sig. \\
\cline { 2 - 4 } & $\mathrm{B}$ & Std. Error & Beta & & \\
\hline 1 (Constant) & 7.562 & 2.148 & & 3.521 & .001 \\
Insentif & .191 & .083 & .372 & 2.301 & .028 \\
\hline
\end{tabular}

a. Dependent Variable: Prestasi Kerja

Berdasarkan tabel di atas menjelaskan pengaruh variable $X$ (Insentif) terhadap prestasi kerja karyawan Housekeeping di Hotel Furaya Pekanbaru memiliki t hitung sebesar 3.521 lebih besar dari t tabel sebesar 1,68957 atau nilai sign $=0,007<\alpha=5 \%$ $(0,007<0,05)$ menyatakan $\mathrm{H}_{0}$ ditolak. Kesimpulannya bahwa Insentif berpengaruh terhadap prestasi kerja karyawan Housekeeping di Hotel Furaya Pekanbaru.

\section{PEMBAHASAN}

Setelah menganalisis dan membahas Pengaruh Pemberian Insentif Terhadap Prestasi Kerja Karyawan Housekeeping Pada Hotel Furaya Pekanbaru, dapat diketahui bahwa nilai koefisien determinasi sebesar 0,238 . Artinya variabel insentif yang terdiri dari insentif finansial dan nonfinansial memberikan kontribusi terhadap variabel prestasi kerja sebesar $23.8 \%$ dan sisanya $76.2 \%$ ditentukan oleh faktor-faktor lain yang tidak diteliti dalam penelitian ini.

Faktor dominan yang mempengaruhi Prestasi Kerja Karyawan Housekeeping Pada Hotel Furaya Pekanbaru adalah faktor finansial $\left(\mathrm{X}_{1}\right)$. Hal ini terlihat dari hasil uji hipotesis bahwa nilai t-hitung lebih besar dari t-tabel yaitu 3.521>1,68957. Berdasarkan hasil penelitian yang dilakukan terdapat hubungan yang signifikan antara insentif dan prestasi kerja karyawan Housekeeping pada Hotel Furaya Pekanbaru, maka H0 ditolak Ha diterima. Dengan kebijakan tersebut lebih memotivasi karyawan untuk bekerja lebih baik guna peningkatan karir kedepannya.

Hasil penelitian ini sejalan dengan yang disampaikan oleh As'ad (2001) bahwa faktor factor yang mempengaruhi prestasi kerja, Prestasi kerja dipengaruhi oleh beberapa factor, untuk mengindentifikasi keseluruhan factor yang mempengaruhi prestasi kerja merupakan suatu upaya yang tidak mudah. Secara umum prestasi kerja melibatkan unsur individu ( psikis dan fisik ) dan lingkungan. Adanya perbedaan antara prestasi kerja antara karyawan dengan karyawan lain dipengaruhi oleh beberapa faktor psikis dan fisik. Termasuk perbedaan faktor fisik adalah bentuk badan dan komposisinya, taraf kesehatan fisik pada umumnya dan taraf kemampuan panca indra, sedangkan yang termasuk faktor psikis adalah intelegensi, bakat minat, kepribadian, motivasi, dan pendidikan. Faktor lingkungan yang dapat mempengaruhi prestasi kerja misalnya, metode kerja, pengaturan dan kondisi perlengkapan kerja, penataan ruang kerja, kebijaksanaan, dll.

Pemberian kompensasi merupakan salah satu pelaksanaan fungsi manajemen sumberdaya manusia yang berhubungan dengan semua jenis pengjargaan individual sebagai pertukaran dalam melakukan tugas keperusahaan. Pengertian kompensasi menurut Simamora (2004 : 540 ) merupakan apa yang diterima oleh para karyawan sebagai ganti kontribusi mereka kepada perusahaan. Kompensasi meliputi kembalian kembalian finansial, jasa jasa terwujud dan tunjangan tunjangan yang diterima oleh para karyawan sebagai bagian dari sebuah hubungan kepegawaian. Kompensasi merupakan keseluruhan balas jasa yang diterima oleh pegawai sebagai akibat pelaksanaan pekerjaan dari perusahaan dalam bentuk uang atau lainnya yang dapat berupa gaji, upah, insentif dan tunjangan lainnya seperti tunjangan hari raya, uang makan dan uang cuti, Hariandja ( 2000:244).

Berdasarkan beberapa pendapat diatas maka dapat disimpulkan bahwa kompensasi merupakan bentuk balas jasa yang diterima oleh karyawan sebagai pengganti atas kontribusi yang mereka berikan terhadap perusahaan dalam bentuk uang atau lainnya..

Menurut Rivai (2004:360-362) komponen komponen kompensasi adalah: Gaji. Gaji adalah balas jasa dalam bentuk uang yang 
diterima karyawan sebagai konsekuensi dari kedudukannya sebagai seorang karyawan yang memberikan sumbangan tenaga dan pikiran untuk mencapai tujuan perusahaan. Atau dapat juga dikatakan sebagai bayaran tetap yang diterima seseorang dari keanggotaanya dalam sebuah perusahaan. Upah. Upah merupakan imbalan finansial langsung yang dibayarkan kepada karyawan berdasarkan jam, jumlah barang yang dihasilkan atau banyyaknya pelayanan yang diberikan. Insentif. Insntif merupakan imbalan langsung yang dibayarkan kepada karyawan karna kenerjanya melebihi standar yang di tentukan. Insntif merupakan bentuk lain dari upak langsung diluar upah dan gaji yang merupakan kompensasi tetap.

\section{SIMPULAN}

Berdasarkan hasil penelitian yang dilakukan terdapat hubungan yang signifikan antara insentif dan prestasi kerja karyawan Housekeeping pada Hotel Furaya Pekanbaru, maka H0 ditolak Ha diterima Dengan kebijakan tersebut lebih memotivasi karyawan untuk bekerja lebih baik guna peningkatan karir kedepannya.

\section{DAFTAR RUJUKAN}

Abdul Rachman Arief. 2005. Pengantar Ilmu Perhotelan dan Restoran. Yogyakarta : Graha Ilmu.

Arikunto Suharsimi. 2006. Prosedur Penelitian, Cetakan keenambelas, Jakarta : Rineka Cipta

Anoymus. 2001. Energy Management and Conservation Guide. Washington : American Hotel and Lodging Foundation.

Anoymus. 2006. Metode Audit Energi dan Implementasi. Malang: Jurusan Teknik Elektro, Universitas Barawijaya.

\begin{tabular}{|c|c|c|}
\hline Andre & Hernowo. & 2010. \\
\hline & $\begin{array}{l}\text { Manajemen, } \\
\text { Bandung. }\end{array}$ & Bandung: \\
\hline
\end{tabular}

Bagyono. 2007. Pariwisata dan Perhotelan, Cetakan Kedua , Bandung : Alfabeta.

Damardjati. 1995. Istilah-istilah Dunia Pariwisata. Jakarta: Pradnya Paramita.

Direktorat Jenderal Pengembangan Energi. 1992. Petunjuk Teknis Konservasi Energi; Prosedur Audit Energi Pada Bangunan Gedung. Jakarta : Departemen Pertambangan dan Energi.

Edison, Emron. 2007. Profesional Hotel Engineering, Bandung: Alfabeta.

Haifa Wahyu. 2010. Manajemen Energi dan Fasilitas Hotel. Bandung: STP Bandung.

Haifa wahyu, dan Tim. 2010. kutipan tugas kelompok mata kuliah Manajemen Energi dan Fasilitas Hotel. STP Bandung.

Indonesia Hotel Industry. 2009. Howarth HTL

Isril Haen. 2010. Manajemen Energi dan Fasilitas Hotel. Bandung: STP Bandung.

Marpaung Happy dan Bahar Herman. 2002. Pengantar Pariwisata, Bandung: Alfabeta.

Nyoman S. Pendit, 2003, Ilmu Pariwisata. Jakrta: Pradnya Paramita.

Oka A. Yoeti, 1996, Pengantar Pariwisata. Bandung: Angkasa.

Oka A. Yoeti, 2003, Hotel Engineering, Jakarta : PT.Perca. 
Rizka Elyza, dkk. 2005. Buku Panduan Efisiensi Energi di Hotel. Jakarta : Pelangi, www.pelangi.or.id

Simatupang Violetta. 2009. Pengaturan Hukum Kepariwisataan Indonesia. Bandung: PT.Alumni.

Sulastiyono, Agus. 2005. Managemen Penyelenggaraan Hotel, Cetakan keduabelas, EdisiPertama, Bandung: Alfabeta.

SNI 03-6196-2000. Prosedur Audit Energi Pada Bangunan Gedung.

Wisnu HS Al Bataafi. 2006. Housekeeping Departement Flour and Public Area. Bandung : Alfabeta. 